\title{
PENGARUH PEMBERIAN INSENTIF TERHADAP KINERJA PEGAWAI PADA BADAN PENGELOLAAN KEUANGAN DAN ASET DAERAH LAMPUNG TENGAH
}

\author{
Muhammad Iqbal $^{(1)}$, Ade Sandra Dewi ${ }^{(2)}$ \\ Fakultas Ekonomi Universitas Sang Bumi Ruwa Jurai \\ m.iqbal29@gmail.com,ade.sandra.dewi@fe.saburai.ac.id
}

\begin{abstract}
Abstrak. Badan Pengelolaan Keuangan dan Aset Daerah Lampung Tengah menghadapi permasalahan realisasi pemberian insentif yang masih belum optimal, terlihat dari masih ada beberapa pegawai yang tidak termotivasi untuk bekerja, kinerja pegawai masih belum optimal, hal ini tercermin dalam pelaksanaan tugas dan fungsi baik secara kualitas dan kuantitas pekerjaan belum memuaskan pimpinan. Tujuan dari penelitian ini adalah Untuk mengetahui Pengaruh Pemberian Insentif terhadap Kinerja Pegawai di Badan Pengelola Keuangan dan Aset Daerah Lampung Tengah. hipotesis dalam penelitian ini adalah Pemberian Insentif memiliki pengaruh positif dan signifikan terhadap Kinerja Pegawai di Badan Pengelola Keuangan dan Aset Daerah Lampung Tengah. Sampel dalam penelitian ini terdiri dari jumlah responden sebanyak 67 orang responden pegawai Badan Pengelola Keuangan dan Aset Daerah (BPKAD) Lampung Tengah. Metode analisis yang digunakan adalah dengan metode regresi linier sederhana. Besarnya Koefisien Determinasi antara Pemberian Insentif $(\mathrm{X})$ dengan Kinerja $(\mathrm{Y})$ adalah $63,68 \%$, hal ini menunjukkan bahwa pengaruh pemberian insentif terhadap kinerja adalah sebesar $63,68 \%$, sedangkan sisanya ditentukan oleh variabel lain. Persamaan regresi antara variabel Pemberian Insentif $(\mathrm{X})$ terhadap Kinerja (Y).
\end{abstract}

Kata kunci: Aset, Insentif, Kinerja, Pegawai.

\section{PENDAHULUAN}

Organisasi didefinisikan sebagai wadah kegiatan dari orang-orang yang bekerjasama dalam usaha mencapai tujuan. Dalam wadah kegiatan itu setiap orang harus jelas tugas, wewenang, tanggung jawabnya, hubungan dan tata kerjanya, sehingga dapat tercapai tujuan organisasi. Suatu organisasi dalam mencapai tujuannya harus memiliki individu-individu dengan kualitas dan kuantitas yang sesuai dan disyaratkan oleh organisasi tersebut. Dalam hal ini organisasi sangat ditentukan oleh kegiatan pendayagunaan SDM, yaitu orang- orang yang menyediakan tenaga, bakat, kreativitas, dan semangat bagi organisasi serta memegang peranan penting dalam fungsi operasional organisasi.
SDM yang cukup berperan pada sebuah organisasi tak lain adalah pegawai. Menyadari peranan dari pegawai yang sangat penting dalam suatu organisasi, maka faktor ini harus dikelola semaksimal mungkin. Pendayagunaan sumber daya manusia di dalam organisasi antara lain dilakukan melalui fungsi- fungsi perencanaan sumber daya manusia, rekruitmen dan seleksi, penempatan sumber daya manusia, pengembangan sumber daya manusia, perencanan dan pengembangan karier, pemberian insentif, budaya kerja, keselamatan, kesehatan kerja, hubungan industrial.

Hal ini dapat dikatakan bahwa organisasi mempunyai tujuan agar dapat memenuhi kebutuhan hidupnya. Oleh sebab itu, organisasi mengharapkan para pegawai dapat berprestasi dan mampu menciptakan situasi dan kondisi yang kondusif, sehingga 
pegawai tidak akan mengalami kejenuhan, kebosanan, dan malas bekerja yang mengakibatkan penurunan kinerja. Kinerja pegawai yang menurun akan mengakibatkan kerugian pada organisasi.

Kinerja pegawai adalah perilaku nyata yang ditampilkan setiap pegawai sebagai prestasi kerja yang dihasilkan sesuai dengan perannya dalam organisasi. Pada setiap orang yang bekerja atau dalam suatu kelompok kerja, kinerja selalu diharapkan bisa senantiasa baik kualitas dan kuantitasnya. Untuk mendapatkan hasil itu sendiri haruslah didukung dengan penetapan tujuan dan diawali dengan perencanaan kerja yang rasional. Maksud penetapan tujuan kinerja adalah menyusun sasaran-sasaran yang berguna tidak hanya sebagai pedoman mencapai tujuan, tetapi juga bisa menjadi sarana evaluasi kinerja pada akhir periode dan untuk mengelola keadaan pasca kerja selama periode tersebut.

Banyak faktor yang dapat mempengaruhi kinerja pegawai salah satunya adalah pemberian insentif. Pemberian penghargaan atau insentif yang memadai kepada pegawai perlu mendapatkan perhatian khusus sehingga mereka dapat melaksanakan tugasnya dan dapat mengembangkan kemampuan mereka semaksimal mungkin. Insentif sangat diperlukan untuk memacu kinerja para pegawai agar selalu berada pada tingkat tertinggi (optimal) sesuai kemampuan masing-masing. Peran insentif cukup besar dalam membentuk pegawai potensial. Insentif merupakan salah satu bentuk pemberian gaji, upah, dan penghargaan yang diberikan kepada pegawai terkait dengan kontribusi pegawai dalam pencapaian tujuan organisasi.

Setiap organisasi memiliki caranya masing-masing untuk meningkatkan efisiensi serta daya saingnya di dalam menghadapi persaingan tersebut. Oleh sebab itu, salah satu cara untuk meningkatkan efesiensi serta daya saingnya, maka organisasi diharapkan mampu mengandalkan serta meningkatkan kualitas sumber daya manusia. Pemerintah telah mengeluarkan penyataan bahwa dalam rangka untuk meningkatkan kinerja penyelenggaraan pemerintah, pelaksanaan pembangunan dan pemberian pelayanan pada kepada masyarakat, maka perlu diberikan tambahan penghasilan atau dikenal dengan istilah insentif kepada Pegawai Negeri Sipil pada Badan Pengelola Keuangan dan Aset Daerah Lampung Tengah.

Hal tersebut dilakukan karena insentif sangat berpengaruh bagi kinerja setiap pegawai demi untuk kesehjahteraan dan kinerja. Berdasarkan pengamatan sementara pada Badan Pengelola Keuangan dan Aset Daerah Lampung Tengah bahwa masih terdapat banyak pegawai tidak maksimal dalam bekerja.

Berdasarkan uraian tersebut, maka peneliti tertarik untuk melakukan penelitian dengan judul: "Pengaruh Pemberian Insentif Terhadap Kinerja Pegawai Pada Badan Pengelola Keuangan dan Aset Daerah Lampung Tengah".

\section{KAJIAN TEORI}

\section{Pengertian Insentif}

Menurut T. Hani Handoko (2014), menyatakan bahwa pengertian insentif adalah: "Perangsang yang ditawarkan kepada para karyawan untuk melaksanakan kerja sesuai atau lebih tinggi dari standarstandar yang telah ditetapkan". Agus Dharma (2014), mengatakan bahwa insentif adalah: "Penghargaan dalam bentuk uang yang diberikan kepada mereka yang dapat bekerja melampaui standar yang telah ditentukan". Sedangkan menurut Malayu SP. Hasibuan (2011), mengatakan bahwa insentif adalah: "Tambahan balas jasa yang 
diberikan kepada karyawan tertentu yang prestasinya diatas prestasi standar".

Menurut Anwar Prabu Mangkungara (2013), mangatakan pengertian insentif adalah: "Suatu penghargaan dalam bentuk uang yang diberikan oleh pihak pemimpin organisasi kepada karyawan agar mereka bekerja dengan motivasi yang tinggi dan berprestasi dalam pencapaian tujuan-tujuan organisasi". Menurut Heidjrachman Ranupandoyo (terjemahan Anwar Prabu Mangkunegara, 2013), mengatakan bahwa pengertian insentif adalah: "Suatu bentuk motivasi yang dinyatakan dalam bentuk uang".

Menurut Veitzhal Rivai (2012), bahwa "Insentif diartikan sebagai bentuk pembayaran yang dikaitkan dengan kinerja dan gaisharing, sebagai pembagian keuntungan bagi karyawan akibat peningkatan produktivitas atau penghematan biaya". Menurut Hadari Nawawi (2003), mengemukakan bahwa insentif adalah: "Penghargaan atau ganjaran yang diberikan untuk memotivasi para karyawan agar produktiviyasnya tinggi dan sifatnya tidak tetap".

Jadi insentif adalah suatu penghargaan dalam bentuk material atau non material yang diberikan oleh pihak pimpinan organisasi perusahaan kepada karyawan agar mereka bekerja dengan motivasi yang tinggi dan berprestasi dalam mencapai tujuan-tujuan perusahaan, dengan kata lain pemberian insentif adalah pemberian uang diluar gaji sebagai pengakuan terhadap prestasi kerja dan kontribusi terhadap karyawan kepada perusahaan.

\section{Indikator Insentif}

Seorang pegawai yang memiliki prestasi kerja yang baik tentunya berhak mendapatkan insentif. Insentif yang diterimanya berbentuk rangsangan yang diberikan kepada manusia agar mau melakukan tindakan. Rangsangan tersebut berupa hadiah-hadiah sebagai balas jasa atas suatu usaha ekstra atau hasil istimewa yang dicapai seorang karyawan. Agus Dharma, (2014) menyatakan bahwa terdapat beberapa indikator insentif, yaitu :

1. Insentif Material

Yaitu daya perangsang yang diberikan kepada karyawan berdasarkan prestasi kerjanya berbentuk uang atau barang. Insentif material ini bernilai ekonomis sehingga dapat meningkatkan kesejahteraan karyawan. Beberapa macam insentif yang diberikan kepada karyawan meliputi:

a) Bonus merupakan uang yang dibayarkan sebagai balas jasa atas hasil pekerjaan yang dilaksanakan. Diberikan selektif dan khusus kepada pekerja yang berhak menerima, serta diberikan berkala sekali terima tanpa adanya suatu ikatan pada masa yang akan datang.

b) Kompensasi yang ditangguhkan (deffered compensation) Dana pensiun memiliki nilai insentif karena memenuhi kebutuhan pokok seseorang yaitu menyediakan jaminan ekonomi setelah ia tidak bekerja lagi.

2. Insentif Non Material

Yaitu daya perangsang yang diberikan kepada karyawan yang berbentuk penghargaan pengukuhan berdasarkan pretasi kerjanya. Beberapa macam insentif non material meliputi:

a) Pemberian gelar secara resmi

b) Pemberian tanda jasa atau medali

c) Pemberian piagam penghargaan

d) Pemberian hak untuk memakai sesuatu atribut jabatan

e) Pemberian perlengkapan khusus pada ruangan kerja

f) Ucapan terima kasih secara formal maupun informal. 
3. Sosial Insentif

Yaitu daya perangsang yang diberikan kepada karyawan berdasarkan prestasi kerjanya berupa fasilitas dan kesempatan untuk mengembangkan kemampuannya seperti promosi, mengikuti pendidikan, naik haji dan lain- lain.

\section{Pengertian Kinerja}

Kinerja berasal dari pengertian performance. Ada pula yang memberikan pengertian performance sebagai hasil kerja atau prestasi kerja. Namun, sebenarnya kinerja mempunyai makna yang lebih luas, bukan hanya hasil kerja, tetapi termasuk bagaimana proses pekerjaan berlangsung, (Wibowo, 2007). Selain itu, pendapat ahli mengatakan kinerja berasal dari kata $J o b$ Performance atau Actual Performance (prestasi kerja atau prestasi sesungguhnya yang dicapai oleh seseorang).

Sudarmanto (2014) menyatakan bahwa kinerja adalah pencapaian atau efektivitas pada tingkat pegawai atau pekerjaan. Kinerja pada level ini dipengaruhi oleh tujuan pekerjaan, rancangan pekerjaan dan manajemen pekerjaan serta karakteristik individu. Pengertian kinerja (prestasi kerja) adalah hasil kerja secara kualitas dan kuantitas yang dicapai oleh seorang pegawai dalam melaksanakan tugasnya sesuai dengan tanggungjawab yang diberikan kepadanya, (Anwar Prabu Mangkunegara, 2013).

\section{Faktor yang Mempengaruhi Kinerja}

Menurut Anwar P. Mangkunegara (2013), terdapat dua faktor yang mempengaruhi kinerja pegawai yaitu :

1. Faktor Individu

Secara psikologis, individu yang normal adalah individu yang memiliki integritas yang tinggi antara fungsi psikis (rohani) dan fisiknya (jasmaniah). Dengan adanya integritas yang tinggi antara fungsi psikis dan fisik maka individu tersebut memiliki konsentrasi diri yang baik. Konsentrasi yang baik ini merupakan modal utama individu manusia untuk mampu mengelola dan mendayagunakan potensi dirinya secara optimal dalam melaksanakan kegiatan atau aktivitas kerja sehari-hari dalam mencapai tujuan organisasi.

2. Faktor Lingkungan Organisasi

Faktor lingkungan kerja organisasi sangat menunjang bagi individu dalam mencapai kinerja. Faktor lingkungan organisasi yang dimaksud antara lain uraian jabatan yang jelas, otoritas yang memadai, target kerja yang menantang, pola komunikasi yang efektif, hubungan kerja yang harmonis, iklim kerja yang respek dan dinamis, peluang berkarir dan fasilitas kerja yang relatif memadai.

Menurut Mathis dan Jakson dalam Mangkunegara (2013), Faktor-faktor yang mempengaruhi kinerja individu tenaga kerja, yaitu:

a) Kemampuan mereka

b) Motivasi

c) Dukungan yang diterima

d) Keberadaan pekerjaan yang mereka lakukan

e) Hubungan mereka dengan organisasi.

\section{METODE PENELITIAN}

\section{Objek Penelitian}

Penelitian ini mengambil lokasi di Badan Pengelola Keuangan dan Aset Daerah (BPKAD) Lampung Tengah yang beralamat di Jl. Raya Padang Ratu, Bumi Aji, Anak Tuha, Kabupaten Lampung Tengah, Lampung. Penelitian dilaksanakan pada Bulan Mei Sampai dengan Juli 2018. 


\section{Metode Penelitian}

Data Primer yaitu data yang dikumpulkan dan diolah sendiri oleh peneliti langsung dari responden. Dalam penelitian ini data primer diperoleh dengan cara memberikan angket (quisioner) kepada responden yaitu pegawai Badan Pengelola Keuangan dan Aset Daerah (BPKAD) Lampung Tengah. Data Sekunder yaitu data yang diperoleh dari pihak lain yang telah mengolah atau mempublikasikan data primer seperti diperoleh dari Jurnal, Majalah Ilmiah, Buletin dan sebagainya.

\section{Metode dan Teknik Pengumpulan Data}

Teknik pengumpulan data merupakan cara-cara yang digunakan oleh peneliti untuk mendapatkan data. Dengan teknik pengumpulan data yang tepat akan dapat diperoleh data yang obyektif, valid dan reliabel.

Teknik pengumpulan data yang diperoleh adalah sebagai berikut :

1. Studi kepustakaan (Library Research), dapat dikumpulkan melalui literatur, tulisan ilmiah yang ada hubungannya dengan permasalahan yang diteliti.

2. Studi lapangan (Field Research), dilakukan langsung ke obyek penelitian, jenis-jenis data yang akan ungkap dengan masin-masing alat antara lain :

a) Observasi, yaitu mengadakan pengamatan langsung pada obyek penelitian

b) Interview, yaitu untuk memperoleh data yang dinilai dapat melengkapi data pokok dengan serangkaian wawancara

c) Kuesioner, yaitu teknik pengumpulan data primer dengan cara mengajukan beberapa pernyataan secaram tertulis dengan alternatif Jawaban yang diajukan kepada responden

d) Dokumentasi, yaitu teknik pengumpulan data dengan cara mengumpulkan melalui buku, jurnal dan tulisan yang ada hubungannya dengan permasalahan yang diteliti.

\section{Populasi dan Sampel}

Sampel penelitian haruslah benar-benar mencerminkan kondisi populasi yang ada. Untuk itu, proses pengambilannya harus melalui serangkaian aturan tertentu yang disebut sampling. Sampling adalah cara atau teknik yang digunakan untuk mengambil sampel atau cara untuk menentukan sampel yang jumlahnya sesuai dengan ukuran sampel yang akan dijadikan sumber data sebenarnya (Sugiyono, 2012).

Menurut pendapat Suharsimi Arikunto (2013) bahwa jika anggota populasi lebih besar dari 100 maka dapat dilakukan metode sampling dengan mangambil sampel sebesar 10 sampai dengan $25 \%$ dari anggota populasi, tetapi jika anggota populasi lebih kecil dari 100 sebaiknya menggunakan metode sensus dengan meneliti seluruh anggota populasi Jumlah populasi pegawai Badan Pengelola Keuangan dan Aset Daerah (BPKAD) Lampung Tengah adalah sebanyak 67 orang.

\section{Metode Analisis}

Analisa kualitatif digunakan sebagai metode untuk menganalisa permasalahan berdasarkan konsep dan teori manajemen sumber daya manusia. Dalam metode ini juga menganalisa masalah dengan teoriteori yang berkaitan dengan masalah Pemberian Insentif dan Kinerja.

Analisis kuantitatif yang digunakan dalam penelitian ini bertujuan untuk mengetahui Pengaruh Pemberian Insentif terhadap Kinerja Pegawai Badan Pengelola 
Keuangan dan Aset Daerah (BPKAD) Lampung Tengah. Analisis regresi digunakan untuk memprediksikan seberapa jauh perubahan nilai variabel dependen, bila nilai variabel independen di manipulasi atau dirubah-rubah atau dinaik- turunkan.

Persamaan Regresi Linear Sederhana menentukan persamaan regresi linear sederhana untuk X :

$$
Y=a+b X+e
$$

Keterangan:

$$
\begin{aligned}
& \mathrm{Y}=\text { Kinerja Pegawai } \\
& \mathrm{a}=\text { Konstanta } \\
& \mathrm{b}=\text { Koefisien regresi } \mathrm{X} \\
& \mathrm{X}=\text { Pemberian Insentif } \\
& \mathrm{e}=\text { Faktor kesalahan }
\end{aligned}
$$

Untuk mengetahui besarnya pengaruh, penghitungan koefisien korelasi tersebut kemudian dilanjutkan dengan Rumus Koefisien Determinasi atau Koefisien Penentu (KP):

$$
K P=(r)^{2} x 100 \%
$$

Untuk menguji secara hipotesis secara parsial digunakan Uji t dengan rumus :

$$
t_{\text {hitung }}=\frac{r \sqrt{N-2}}{\sqrt{1-r^{2}}}
$$

Keterangan:

$$
\begin{aligned}
& \mathrm{t}_{\text {hitung }} \quad=\text { Nilai } \mathrm{t} \\
& \mathrm{r}=\text { Koefisien Korelasi } \\
& \mathrm{N} \quad=\text { Jumlah responden } \\
& \text { (Sugiyono, 2008). }
\end{aligned}
$$

Kriteria untuk Uji $\mathrm{t}$ adalah sebagai berikut :

a) Jika $t_{\text {hitung }}>t_{\text {tabel }}$ maka Ha diterima dan Ho ditolak.

b) Jika $t_{\text {hitung }} \leq t_{\text {tabel }}$ maka Ha ditolak dan Ho diterima.

\section{HASIL DAN PEMBAHASAN}

Variabel penelitian terdiri dari satu variabel dependent yaitu Kinerja (Y) dan satu variabel independent yaitu Pemberian Insentif (X). Jumlah objek penelitian yang dianalisis sebanyak 67 Responden yang akan diuraikan selanjutnya menurut jenis kelamin dan tingkat pendidikan. Dalam instrumen penelitian dalam bentuk kuesioner terdapat lima alternatif jawaban, dan setiap alternatif jawaban tersebut memiliki skor yang berbeda. Maka dalam memberikan deskripsi data yang dikumpulkan ini juga menggunakan ukuran deskripsi yang sama, dengan menggunakan teknik distribusi frekuensi.

\section{Uji Validitas dan Reliabilitas Pemberian Insentif (X)}

Uji validitas untuk setiap pernyataan variabel Pemberian Insentif tertinggi adalah sebesar 0,736 dan terendah adalah sebesar 0,290 . Dengan tingkat kepercayaan sebesar 95\% dan jumlah $\mathrm{n}$ sebesar 67 , diperoleh nilai pada tabel distribusi $\mathrm{r}$ sebesar 0,2423 , maka setiap pernyataan pada variabel Pemberian Insentif dinyatakan telah memenuhi tingkat validitas.

Reliabilitas pernyataan variabel Pemberian Insentif dengan jumlah sampel ( $N$ of Cases) sebanyak 67 Responden dan jumlah item pernyataan ( $N$ of Items) sebanyak 10, diperoleh alpha total sebesar 0,830 . Dari 10 item pernyataan nilai Cronbach's alpha if item deleted seluruhnya menunjukkan reliabel, karena nilai 10 item pernyataan lebih besar dari 0,60 .

\section{Uji Validitas dan Reliabilitas Kinerja (Y)}

Uji validitas untuk setiap pernyataan variabel Kinerja tertinggi adalah sebesar 0,725 dan terendah adalah sebesar 0,274. Dengan tingkat kepercayaan sebesar $95 \%$ 
dan jumlah $\mathrm{n}$ sebesar 67, diperoleh nilai pada tabel distribusi $r$ sebesar 0,2423, maka setiap pernyataan pada variabel Kinerja dinyatakan telah memenuhi tingkat validitas.

Reliabilitas pernyataan variabel Kinerja dengan jumlah sampel ( $N$ of Cases) sebanyak 67 Responden dan jumlah item pernyataan ( $N$ of Items) sebanyak 10 , diperoleh alpha total sebesar 0,778. Dari 10 item pernyataan nilai cronbach's alpha if item deleted seluruhnya menunjukkan reliabel, karena nilai 10 item pernyataan lebih besar dari 0,60.

\section{Analisis Kuantitatif}

Persamaan regresi antara variabel Pemberian Insentif (X) terhadap Kinerja (Y) adalah $\mathrm{Y}=1,246+0,671 \mathrm{X}$, yang artinya setiap kenaikan satu point dari variabel Pemberian Insentif akan diikuti oleh variabel Kinerja sebesar 0,671 point. Koefisien Determinasi $(\mathrm{KD})=\mathrm{R} 2=0,7982$ $=0,6368=0,6368 \times 100 \%=63,68 \%$. Dapat disimpulkan bahwa variabel Pemberian Insentif (X) menjelaskan variasi perubahan variabel Kinerja (Y) sebesar $63,68 \%$, sedangkan sisanya dijelaskan oleh faktor lain yang tidak dikaji dalam penelitian ini.

Berdasarkan hasil Uji $\mathrm{t}$ didapat nilai $\mathrm{t}_{\text {hitung }}=3,922$. Apabila dibandingkan dengan $t_{\text {tabel }}$ pada taraf signifikan yaitu 1,67, maka $t_{\text {hitung }}=3,922>t_{\text {tabel }}=1,67$. sehingga hipotesis yang menyatakan terdapat pengaruh antara Variabel Pemberian Insentif (X) dengan Kinerja (Y) pada Badan Pengelola Keuangan dan Aset Daerah (BPKAD) Lampung Tengah dapat diterima.

Pemberian insentif yang tepat di samping untuk meningkatkan kinerja pegawai, dimaksudkan pula untuk membuat pegawai memiliki kesetiaan bekerja di instansi dan dapat menstabilkan perputaran tenaga kerja. Dengan adanya insentif, Badan Pengelola Keuangan dan Aset Daerah Lampung Tengah mengharapkan dapat meningkatkan kinerja pegawai, menurunkan tingkat absensi maupun perputaran tenaga kerja, sehingga hal tersebut dapat mendorong pegawai bekerja dengan lebih giat, semangat dan penuh rasa tanggung jawab terhadap pekerjaannya.

Berdasarkan hasil penelitian diketahui bahwa besarnya Koefisien Determinasi antara Pemberian Insentif (X) dengan Kinerja $(\mathrm{Y})$ adalah $\mathrm{KD}=\mathrm{R} 2=0,7982=$ $0,6368=0,6368 \times 100 \%=63,68 \%$. Uji hipotesis parsial melalui uji $t$ (test) diperoleh nilai thitung antara Pemberian Insentif (X) dengan Variabel Kinerja (Y) sebesar $=3,922$ dan thitung 3,922 > ttabel 1,67. Persamaan regresi antara variabel Pemberian Insentif (X) terhadap Kinerja (Y) adalah $\mathrm{Y}=1,246+0,671 \mathrm{X}$, yang artinya setiap kenaikan satu point dari variabel Pemberian Insentif akan diikuti oleh variabel Kinerja sebesar 0,671 point. Hal ini menunjukkan bahwa Pemberian Insentif berpengaruh terhadap Kinerja pegawai.

\section{KESIMPULAN DAN SARAN}

\section{Kesimpulan}

Berdasarkan analisis dan pembahasan maka dapat diambil kesimpulan bahwa, besarnya Koefisien Determinasi antara Pemberian Insentif (X) dengan Kinerja (Y) adalah 63,68\%. Berarti Pengaruh Pemberian Insentif terhadap Kinerja adalah sebesar 63,68\%, sedangkan sisanya ditentukan oleh variabel lain. Persamaan regresi antara variabel Pemberian Insentif (X) terhadap Kinerja (Y) adalah Y $=1,246+$ $0,671 \mathrm{X}$, yang artinya setiap kenaikan satu point dari variabel Pemberian Insentif akan diikuti oleh variabel Kinerja sebesar 0,671 point. Hal ini menunjukkan bahwa 
Pemberian Insentif berpengaruh terhadap Kinerja pegawai.

\section{Saran}

Berdasarkan hasil penelitian, pembahasan, dan kesimpulan yang diperoleh, maka saran yang dapat diberikan adalah pimpinan dalam organisasi hendaknya memberikan perhatian yang lebih terhadap aspek pemberian insentif yang tepat waktu sehingga dapat meningkatkan kinerja pegawai sehingga tujuan organisasi dapat dicapai dengan baik dan optimal, serta kelancaran pelaksanaan kegiatan tetap terjamin.

\section{DAFTAR PUSTAKA}

Arikunto, Suharsimi . 2013. Prosedur Penelitian suatu Pendekatan Praktik. Jakarta: Rineka Cipta.

Dharma, Agus. 2014. Manajemen Supervisi. Jakarta: Raja Grafindo Persada.

Handoko, T.Hani. 2014. Manajemen Personalia dan Sumber Daya Manusia. Yogyakarta: BPFE.

Hasibuan, Malayu S.P. 2011. Manajemen Sumber Daya Manusia. Jakarta: PT Bumi. Aksara.

Hasibuan, P.S. Malayu. 2014. Manajemen Sumber Daya Manusia. Jakarta: PT. Bumi Aksara.

Mangkunegara, Anwar Prabu. 2013. Manajemen Sumber Daya Manusia. Bandung: Remaja Rosdakarya.

Nawawi, Hadari. 2003, Manajemen Sumber Daya Manusia: Untuk Bisnis Yang Kompetitif. Yogyakarta: Gajahmada University Press.
Panggabean, S., Mutiara. 2014. Manajemen Sumber Daya Manusia. Bogor: Ghalia Indonesia.

Sudarmanto. 2014. Kinerja dan Pengembangan Kompensasi SDM. Yogyakarta: Pustaka Pelajar.

Sudjana. 2009. Metode Statistik. Jakarta: Rineka Cipta.

Sugiyono. 2012. Metode Penelitian Kuantitatif Kualitatif dan $R \& D$. Bandung: Alfabeta.

Sugiyono. 2014. Metode Penelitian Kuantitatif Kualitatif dan $R \& D$. Bandung: Alfabeta.

Sunyoto. 2013. Metodologi Penelitian Akuntansi. Bandung: PT Refika.

Veithzal Rivai, 2012, Manajemen Sumber Daya Manusia Untuk Perusahaan, Cetakan Pertama. Jakarta: PT. Raja Grafindo Persada.

Wibowo. 2007. Manajemen Kinerja. Jakarta: PT. Raja Grafindo Parsada.

Widodo, Suparno. 2015. Manajemen Pengembangan Sumber Daya Manusia.Yogyakarta: Pustaka Pelajar.

Wiratna, Sujarweni. 2015. SPSS Untuk Penelitian. Yogyakarta: Pustaka Baru. 